https://doi.org/10.1038/s41467-020-14602-8 OPEN

\title{
Author Correction: Extreme intratumour heterogeneity and driver evolution in mismatch repair deficient gastro-oesophageal cancer
}

Katharina von Loga (1), Andrew Woolston (1), Marco Punta, Louise J. Barber, Beatrice Griffiths, Maria Semiannikova, Georgia Spain, Benjamin Challoner (1), Kerry Fenwick, Ronald Simon, Andreas Marx, Guido Sauter, Stefano Lise (1), Nik Matthews \& Marco Gerlinger (1)

Correction to: Nature Communications https:/doi.org/10.1038/s41467-019-13915-7, published online 16 January 2020.

The original version of this Article omitted the following funding source from the Acknowledgements:

The study was supported by grants from the Schottlander Research Charitable Trust.

This has been corrected in the PDF and HTML versions of the Article.

Published online: 29 January 2020

(c) Open Access This article is licensed under a Creative Commons Attribution 4.0 International License, which permits use, sharing, adaptation, distribution and reproduction in any medium or format, as long as you give appropriate credit to the original author(s) and the source, provide a link to the Creative Commons license, and indicate if changes were made. The images or other third party material in this article are included in the article's Creative Commons license, unless indicated otherwise in a credit line to the material. If material is not included in the article's Creative Commons license and your intended use is not permitted by statutory regulation or exceeds the permitted use, you will need to obtain permission directly from the copyright holder. To view a copy of this license, visit http://creativecommons.org/licenses/by/4.0/.

(c) The Author(s) 2020 